\title{
Various antioxidant assays of agarwood extracts (Gyrinops versteegii) from West Lombok, West Nusa Tenggara, Indonesia
}

\author{
AMALIA INDAH PRIHANTINI ${ }^{\vee}$, KANTI DEWI RIZQIANI \\ ${ }^{1}$ Research and Development Institute of Non Timber Forest Product Technology, Research, Development, and Innovation Agency, \\ Ministry of Environment and Forestry, Republic Indonesia. Jl. Dharma Bhakti No.7, Langko, Lingsar, West Lombok 83371, West Nu sa Tenggara, \\ Indonesia, Tel.: +62-370-6175552, Fax.: +62-370-6175482, `email: amaliaindah2@ gmail.com
}

Manuscript received: 26 September 2018. Revision accepted: 3 January 2019.

\begin{abstract}
Prihantini AI, Rizqiani K. 2019. Various antioxidant assays of agarwood extracts (Gyrinops versteegii) from West Lombok, West Nusa Tenggara, Indonesia. Asian J Agric 3: 1-5. Agarwood extracts (Gyrinops versteegii) have not been widely explored as a source of natural products in particular antioxidant agents, which protect cells from damage caused by free radicals. The present study was aimed to evaluate antioxidant activities of agarwood extracts from West Nusa Tenggara using various antioxidant assays. The antioxidant activity of leaf, fruit and fruit bark extracts was investigated based on DPPH radicals scavenging activity, reducing power, and $\beta$-carotene bleaching assays. The total phenolic content was also investigated. The result showed that leaf extract revealed the strongest antioxidant activity on all assays performed such as DPPH radicals scavenging activity $\left(\mathrm{IC}_{50} 22.13 \pm 0.71 \mu \mathrm{g} / \mathrm{mL}\right.$ ); reducing power $(251.85 \pm 0.03 \mathrm{mg} \mathrm{QE} / \mathrm{g}$ dry extract); and $\beta$-carotene bleaching activity (IC $5024.23 \pm 2.60 \mu \mathrm{g} / \mathrm{mL}$ ). The total phenolic content (TPC) in the leaf was higher $(184.90 \pm 0.76 \mathrm{mg} \mathrm{GAE} / \mathrm{g}$ dry extract) than fruit bark and bark extracts. The high content of phenolic compounds in G. versteegii leaves indicated that these compounds might contribute to the antioxidant activities. In conclusion, these findings showed that $G$. versteegii leaves are potential for development as an antioxidant source.
\end{abstract}

Keywords: Agarwood, antioxidant, Gyrinops versteegii, West Nusa Tenggara

\section{INTRODUCTION}

Free radicals have an important role in our health Reactive Oxygen Species (ROS) which are generated from oxygen, can lead to oxidative stress with the affection of various biological functions and structural changes during metabolism or other activities if it is increased and imbalanced between producing radical and antioxidant (Nimse and Pal 2015; Ramamoorthy and Bono 2007; Zima et al. 2001). This oxidative stress can cause a disturbance in numerous physiological processes and development to many degenerative disorders, such as cancer, cardiovascular, Alzheimer disease, neurodegenerative disease, asthma, autoimmune and gastrointestinal diseases, and the aging process (Siti et al. 2015; Arituluk et al. 2016; WojtunikKulesza 2016).

The radicals can be overcome by antioxidants. Antioxidants are compounds that can inhibit ROS, reactive nitrogen species and other free radicals to prevent damage in normal cells, proteins and fats which ultimately prevent degenerative diseases (Arif et al. 2014). Presently, synthetic antioxidants commonly used such as butylated hydroxytoluene (BHT) and butylated hydroxyanisole (BHA) might affect genotoxic, carcinogenic effects, and hemorrhaging (Babbar et al. 2010; Salamah et al. 2011; Stankovic 2014). Due to this reason, natural antioxidant sources might be found to substitute synthetic antioxidants.

Agarwood is considered precious plant in the world, particularly in Asia, due to its high value of resin impregnated-heartwood from the family of Thymelaeaceae
(Ismail et al. 2015). In Indonesia, agarwood is generally grown in Borneo (12 species), Sumatra (10 species), Nusa Tenggara (3 species), Papua (2 species), Sulawesi (2 species), Java (2 species), and Moluccas (1 species). The common main genus of agarwood in Indonesia are Aquilaria malaccensis, A. microcarpa, A. beccariana, A. hirta, A. filaria, A. cumingiana and Gyrinops (Hadi et al. 2011; Santoso et al. 2014). Gyrinops versteegii (Gilg.) Domke is an endemic agarwood that is in Lombok, West Nusa Tenggara Province. Most people in this area use it for resin production. The inoculation of fungi into the agarwood is conducted at the optimal age of the tree to produce optimal yield of resin. During waiting for the harvest of agarwood, certain communities use the agarwood leaves as a herbal tea which is believed that it is effective to cure various diseases including malaria, tumor, fatigue fever and flu symptoms (Nuringtyas et al. 2018). Mega and Swastini (2010) proposed that agarwood leaf extract contains secondary metabolites such as flavonoids, terpenoids and phenol compounds. These secondary metabolites were suspected to have antioxidant activities. Therefore, the aim of this study is to evaluate the antioxidant activities from leaves, fruits, and fruit barks of G. versteegii using various antioxidant assays. 


\section{MATERIALS AND METHODS}

\section{Extract preparation}

Fresh and healthy leaves, fruits, and fruit barks of $G$. versteegii were dried at room temperature and blended. Approximately $20 \mathrm{~g}$ of the dried materials were extracted with methanol. The methanol extracts were then filtered and concentrated under a vacuum rotary evaporator and dried at room temperature prior to antioxidant assays.

\section{DPPH radical scavenging activity assay}

DPPH free radicals scavenging activity was evaluated according to Prihantini et al. (2014). Various concentrations of each sample were mixed with $0.5 \mathrm{~mL}$ of the $1 \mathrm{mM}$ DPPH radical solution in methanol. For the control, a similar solution with the absence of sample was used. Samples were then incubated at room temperature under dark conditions for about $30 \mathrm{~min}$. Absorbance (A) was measured with a spectrophotometer at $517 \mathrm{~nm}$. The percentage of scavenging activity was determined by the following equation:

Scavenging activity $(\%)=\left[\left(\mathrm{A}_{\text {control }}-\mathrm{A}_{\text {sample }}\right) / \mathrm{A}_{\text {control }}\right] \times 100 \%$

\section{$\beta$-carotene bleaching assay}

The $\beta$-carotene bleaching assay was performed according to Prihantini et al. (2014). Approximately $0.2 \mathrm{mg}$ of $\beta$-carotene, $20 \mathrm{mg}$ of linoleic acid and $200 \mathrm{mg}$ of Tween 40 were mixed in $0.5 \mathrm{~mL}$ chloroform, which was then removed using a rotary evaporator at $40^{\circ} \mathrm{C}$. The resulting mixture was diluted with distilled water and mixed vigorously. The mixtures were made up to $50 \mathrm{~mL}$ and aliquots $(4.8 \mathrm{~mL})$ were added to test tubes containing various concentrations of each sample and methanol (control). A similar mixture without $\beta$-carotene was used for the background of the samples. The tubes were incubated at $50^{\circ} \mathrm{C}$ for $2 \mathrm{~h}$. The absorbance at $470 \mathrm{~nm}$ was measured at 0 min either for the control $\left(\mathrm{A}_{\mathrm{c} 0}\right)$ or samples $\left(\mathrm{A}_{\mathrm{s} 0}\right)$. The absorbance of both the control $\left(\mathrm{A}_{\mathrm{c} 120}\right)$ and samples $\left(\mathrm{A}_{\mathrm{s} 120}\right)$ was measured after 120 min incubation. Furthermore, the antioxidant activity was evaluated with the following equation:

$$
\text { Antioxidant activity }(\%)=100\left[1-\left(\mathrm{A}_{\mathrm{c} 0}-\mathrm{A}_{\mathrm{s} 0}\right) /\left(\mathrm{A}_{\mathrm{c} 120}-\mathrm{A}_{\mathrm{s} 120}\right)\right]
$$

\section{Reducing power assay}

The reducing power assay was performed according to Prihantini et al. (2014). Approximately $0.5 \mathrm{~mL}$ of various concentrations of samples in methanol was mixed with phosphate buffer $(2.5 \mathrm{~mL}, 0.2 \mathrm{M}, \mathrm{pH} 6.6)$ and potassium ferry-cyanide $(2.5 \mathrm{~mL}, 1 \%)$. Trichloroacetic acid $(2.5 \mathrm{~mL}$, $10 \%$ ) was added to the mixture after $20 \mathrm{~min}$ incubation at $50^{\circ} \mathrm{C}$. Then, the mixture was centrifuged at $3000 \mathrm{rpm}$ for $10 \mathrm{~min}$. The upper layer solution $(2.5 \mathrm{~mL})$ was mixed with distilled water $(2.5 \mathrm{~mL})$ and ferric chloride solution $(0.5$ $\mathrm{mL}, 0.1 \%)$. Absorbance was measured with a spectrophotometer at $700 \mathrm{~nm}$. The reducing power assay was measured as quercetin equivalent.

\section{Total phenolic content}

The total phenolic content (TPC) of plant extracts was determined using Folin-Ciocalteu reagent (Prihantini et al. 2014). Approximately $500 \mu \mathrm{L}$ of the extracts $\left(1.0 \mathrm{mg} \mathrm{mL}^{-1}\right)$ was added with distilled water, made up to $8 \mathrm{~mL}$ and then mixed with $500 \mu \mathrm{L}$ of $2 \mathrm{~N}$ Folin-Ciocalteu reagents. The mixture was allowed to stand for $8 \mathrm{~min}$ and $1.5 \mathrm{~mL}$ of $20 \%$ sodium carbonate was then added. The reaction mixture was incubated at room temperature for $2 \mathrm{~h}$. Absorbance was measured at $765 \mathrm{~nm}$ and the phenolic content was determined using a calibration curve obtained from concentration of gallic acid.

\section{Statistical analysis}

All assays were performed in triplicate in independent three experiments. The data were expressed as the Mean+S.D value and analyzed by SPSS for windows followed by Tukey's post hoc test. Values with $\mathrm{p}<0.05$ were considered statistically significant.

\section{RESULTS AND DISCUSSION}

There are increasing focuses on products extracted from nature to treat many human diseases. Antioxidant helps our body in prevention and healing process of oxidative stress caused by free radicals. A natural antioxidant can be extracted from plants (Chirag et al. 2013; Krishnaiah et al. 2011; Prihantini et al. 2015). However, due to the complex nature of phytochemicals, various antioxidant assays are necessary to evaluate antioxidant activity. Furthermore, total phenolic contents assay is also commonly used to complement antioxidant assays.

\section{DPPH radicals scavenging activity}

DPPH radicals scavenging assay is a common method to evaluate antioxidant activity of nature. The DPPH assay reflects a scavenging reaction between DPPH and the related samples. DPPH is a stable free radical, which turns from purple to yellow when it is scavenged by antioxidants as hydrogen donors. The delocalization of the DPPH radicals determines the occurrence of a purple color. When DPPH radical (2,2-diphenyl-1-picrylhydrazyl) reacts with a hydrogen donor, the stable molecule (2,2-diphenyl-1hydrazine) is generated resulting in the discoloration of the purple color (Pisoschi and Negulescu 2011). The degree of discoloration indicates the scavenging potential hydrogen donating ability of the related samples.

The study revealed that leaf extract of $G$. versteegii showed the highest activity than others with $\mathrm{IC}_{50}$ $22.13 \pm 0.71 \mu \mathrm{g} / \mathrm{ml}$ followed by fruit bark $(76.87 \pm 3.64$ $\mu \mathrm{g} / \mathrm{ml})$ and bark extracts $(119.49 \pm 3.84 \mu \mathrm{g} / \mathrm{ml})$, and it is significantly different activities $(\mathrm{p}<0.05)$ among the extracts (Table 1). The result indicates that leaf extract has the most potential ability on hydrogen donation. The higher activity of leaf extract was also reported by Mahdi-Pour et al. (2012). 
Table 1. DPPH radicals scavenging activity and $\beta$-carotene bleaching activity of $G$. versteegii

\begin{tabular}{lcc}
\hline Extracts & $\begin{array}{c}\mathbf{I C}_{\mathbf{5 0}} \text { on DPPH radicals } \\
\text { scavenging activity } \\
(\boldsymbol{\mu g} / \mathbf{m l})\end{array}$ & $\begin{array}{c}\mathbf{I C}_{\mathbf{5 0}} \text { on } \boldsymbol{\beta} \text {-Carotene } \\
\text { bleaching activity } \\
(\boldsymbol{\mu g} / \mathbf{m L})\end{array}$ \\
\hline Leaf & $22.13 \pm 0.71^{\mathrm{b}}$ & $24.23 \pm 2.60^{\mathrm{a}}$ \\
Bark & $119.49 \pm 3.84^{\mathrm{d}}$ & $104.97 \pm 0.1^{\mathrm{c}}$ \\
Fruit bark & $76.87 \pm 3.64^{\mathrm{c}}$ & $35.18 \pm 1.27^{\mathrm{b}}$ \\
Quercetin* & $7.4 \pm 0.1^{\mathrm{a}}$ & n.a
\end{tabular}

Note: Data is expressed as Mean \pm S.D values, different letters in the same column indicate significant differences $(p<0.05)$ at Tukey's post hoc test, n.a: Not available, *: Prihantini et al. (2014)

Table 2. Reducing power of G. versteegii

\begin{tabular}{lc}
\hline Extracts & Reducing power $(\mathbf{m g}$ QE/g dry extract $)$ \\
\hline Leaf & $233.89 \pm 14.14^{\mathrm{c}}$ \\
Bark & $99.44 \pm 5.50^{\mathrm{a}}$ \\
Fruit bark & $122.78 \pm 7.38^{\mathrm{b}}$ \\
\hline N &
\end{tabular}

Note: Data is expressed as Mean \pm S.D values, different letters in the same column indicate significant differences $(p<0.05)$ at Tukey's post hoc test, QE: Quercetin equivalent

However, in some cases, the assay gives incorrect results and recommendations. Some complications could be caused by partial ionization of the related samples, which affect the rate of their reaction with DPPH radicals (Tirzitis and Bartosz 2010). Therefore, other antioxidant assays are necessary to confirm and consider the recommendations.

\section{$\beta$-carotene bleaching activity}

$\beta$-carotene bleaching assay is another assay to evaluate antioxidant activity of nature. It performs discoloration in the absence of an antioxidant compound. Therefore, the presences of antioxidant molecules inhibit the extent of $\beta$ carotene bleaching caused by linoleic-free radicals. The radicals may attack the double bonds of $\beta$-carotene and cause discoloration. Antioxidants reduce the discoloration of $\beta$-carotene by stabilizing the linoleic-free radical and other radicals formed in the system (Jayaprakasha et al. 2001).

$\beta$-carotene bleaching activity of leaf, bark, and fruit bark extracts of $G$. versteegii is shown in Table 1 . As DPPH radical scavenging activity, the leaf extract had the highest activity $\left(\mathrm{IC}_{50} 24.23 \pm 2.60 \mu \mathrm{g} / \mathrm{mL}\right)$ compared to other extracts. The result showed that the activity was statistically significantly different with fruit bark and bark at $\mathrm{IC}_{50} 35.18 \pm 1.27$ and $104.97 \pm 0.1 \mu \mathrm{g} / \mathrm{mL}$, respectively. It indicates that leaf extract compounds had high capability of neutralizing the free radicals generated in the system. It is known that $\beta$-carotene assay has a different mechanism involved in the method compared with DPPH assay (Prihantini and Tachibana 2017). However, the present study results in a similar order of the antioxidant activity. Therefore, the result of $\beta$-carotene bleaching activity supports the potential order of antioxidant activity as leaf $>$ fruit bark > bark as the result of DPPH radicals scavenging activity.

\section{Reducing power}

Reducing power may serve as a significant indicator of the potential antioxidant activity. Compounds with reducing power indicate that they are electron donors. The presence of antioxidants causes the conversion of ferricyanide $\left(\mathrm{Fe}^{3+}\right)$ complex in the system to ferrocyanide $\left(\mathrm{Fe}^{2+}\right)$ by donating their electrons. The ferrocyanide then reacts with ferric chloride to form ferric ferrous complex (Pearl's Prussian blue). By measuring the formation of Pearl's Prussian blue at $700 \mathrm{~nm}$, it is possible to determine the concentration of $\mathrm{Fe}^{3+}$ ion electrons (Jayanthi and Lalitha 2011). The result of reducing power of $G$. versteegii is shown in Table 2 . The reducing power activity is shown as quercetin equivalent (QE). The higher quercetin equivalent indicates the higher reducing power of the extract. Extracts showing high reducing power activity indicate an enhanced capability to donate electrons.

The reducing power assay revealed leaf extract with the highest value, followed by fruit bark, and bark extracts $(233.89 \pm 14.14 ; 122.78 \pm 7.38 ; 99.44 \pm 5.50 \mathrm{mg}$ QE/g dry extract, respectively). A similar trend as DPPH radical scavenging activity and $\beta$-carotene bleaching activity, resulted in statistically significantly different at $P<0.05$ among the extracts. Therefore, the result suggested that leaf extract of $G$. versteegii had high capability to donate electrons. Furthermore, the reducing ability was found to be concentration-dependent in which the reducing power increased with the increasing of the concentrations as shown in Figure 1. Higher absorbance of the reaction mixture indicates higher reduction ability (Jayanthi and Lalitha 2011).

\section{Total phenolic content}

Most phenolic compounds consist in the plant. Phenolic compounds are considered to play a role against a wide range of diseases (Ibrahim et al. 2012). The total phenolic content of $G$. versteegii is shown in Table 3. The results were expressed in gallic acid equivalent.

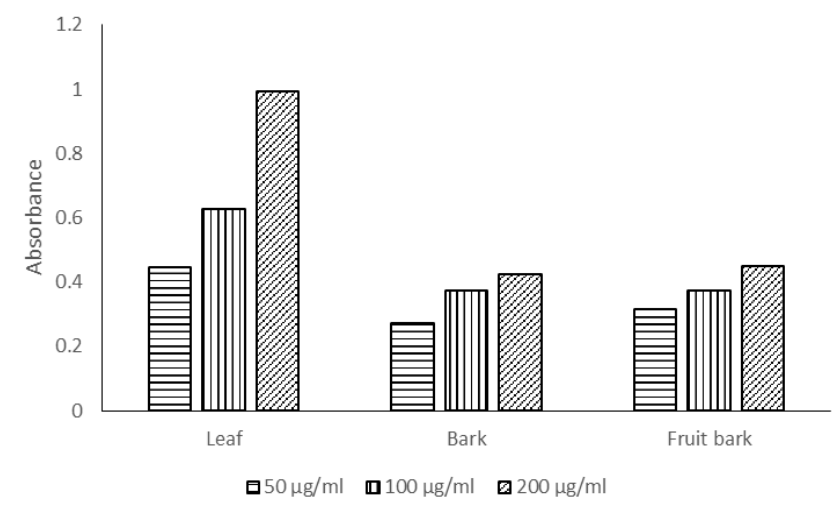

Figure 1. Reducing power assay of $G$. versteegii at different concentrations 
Table 3. Total phenolic content of G. versteegii

\begin{tabular}{lc}
\hline Extracts & $\begin{array}{c}\text { Total phenolic content (mg GAE/g dry } \\
\text { extract) }\end{array}$ \\
\hline Leaf & $184.90 \pm 0.76^{\mathrm{c}}$ \\
Bark & $67.65 \pm 0.23^{\mathrm{a}}$ \\
Fruit bark & $113.02 \pm 0.38^{\mathrm{b}}$ \\
\hline
\end{tabular}

Note: Data is expressed as Mean \pm S.D values, different letters in the same column indicate significant differences $(p<0.05)$ at Tukey's post hoc test, GAE: Gallic acid equivalent

The results showed that leaf extract had the highest total phenolic content, followed by fruit bark and bark extracts $(184.90 \pm 0.76 ; 113.02 \pm 0.38 ; 67.65 \pm 0.23 \mathrm{mg}$ GAE/g dry extract, respectively). It was statistically significant difference among the extracts at $P<0.05$. The highest total phenolic content of leaf extract might be assumed that phenolic compounds present in the extract, gave contribution to the antioxidant activity in DPPH radicals scavenging assay, reducing power, and $\beta$-carotene bleaching assay. Phenolics can donate their electrons to stabilize radicals (Chanda and Dave, 2009; Seal, 2012). Furthermore, the donation of a hydrogen atom that stabilizes the free radicals is considered from phenolic hydroxyl groups (Prihantini et al. 2015). Other studies also reported that the phenolic hydroxyl group is excellent to scavenge free radicals (Jeong et al. 2007; Moalin et al. 2011). The electron donation is without resulting themselves reactive radicals, therefore suggesting that phenolics are considered as a good antioxidant. Furthermore, revealing a similar order of extract having the potencies in all assayed performed, the result is consistent with the findings of several studies in reporting correlation between antioxidant activity and total phenolic content. In conclusion, all the antioxidant assays investigated in the study revealed that leaf extract had the highest antioxidant activity. This indicates that $G$. versteegii leaves have potential to be developed as natural antioxidant sources.

\section{ACKNOWLEDGEMENTS}

We thank Prof. Sanro Tachibana, Dr. Asep Hidayat and Dr. Agus Sukito for their support and kind help during the research.

\section{REFERENCES}

Arif Y, Jose C, Teruna HY. 2014. Total phenolic, flavonoid contents and antioxidant activity of $n$-hexane, dichloromethane, and methanol of Amaranthus spinosus L EM5-garlic. JOM FMIPA 1(2): 359-369. [Indonesian]

Arituluk ZC, Tatli-Cankaya II, Gencler-Ozkan AM. 2016. Antioxidant activity, total phenolic and flavonoid contents of some Tanacetum $\mathrm{L}$. (Asteraceae) Taxa growing in turkey. J Pharm Sci 41: 17-25.

Babbar N, Oberoi HS, Uppal DS, Patil RT. 2010. Total phenolic content and antioxidant capacity of extracts obtained from six important fruit residues. Food Res Int 44: 391-396.

Chanda S and Dave R. 2009. In vitro models for antioxidant activity evaluation and some medicinal plants possessing antioxidant properties: an overview. Afr J Microbiol Res 3: 981-996.
Chirag PJ, Tyagi S, Halligudi N, Yadav J, Pathak S, Singh SP, Pandey A, Kamboj DS, Shankar P. 2013. Antioxidant activity of herbal plants: a recent review. J Drug Discov Ther 1(8):01-08.

Hadi S, Muliasari H, Sukma NS, Ratnaningsih PEW. 2011. Phytochemical screening and antibacterial testing of gaharu trees (Gyrinops versteegii (Gilg) Domke) from Lombok island. Proceedings of the 2nd International Seminar on Chemistry 2011 (pp. 79-82), Jatinangor 24-25 November 2011. [Indonesian]

Ibrahim MH, Jaafar HZ, Karimi E, Ghasemzadeh A. 2012. Primary, secondary metabolites, photosynthetic capacity and antioxidant activity of the Malaysian herb Kacip Fatimah (Labisia Pumila Benth) exposed to potassium fertilization under greenhouse conditions. Int $\mathbf{J}$ Mol Sci 13(11): 15321-15342.

Ismail N, Rahiman MHF, Taib MN, Ibrahim M, Zareen S, Tajuddin SN. 2015. A review on agarwood and its quality determination. IEEE $6^{\text {th }}$ Control and System Graduate Research Colloquium, UiTM Shah Alam, Malaysia, 10-11

Jayanthi P and Lalitha P. 2011. Reducing power of the solvent extracts of Eichhornia crassipes (Mart.) Solms. Int J Pharm Pharm Sci 3(3):126128.

Jayaprakasha GK, Singh RP, Sakariah KK. 2001. Antioxidant activity of grape seed (Vitis vinifera) extracts on peroxidation models in vitro. Food Chem 73:285-290.

Jeong J.M., Kang S.K., Lee I.H., Lee J.Y., Jung H., Choi C.H. 2007. Antioxidant and chemosensitizing effects of flavonoids with hydroxyl and/or methoxy groups and structure-activity relationship. J Pharm Pharm Sci 10:537-546.

Krishnaiah D, Sarbatly R, Nithyanandam R. 2011. A review of the antioxidant potential of medicinal plant species. Food Bioprod Process 89(3):217-233.

Mahdi-Pour B, Jothy SL, Latha LY, Chen Y, Sasidharan S. 2012. Antioxidant activity of methanol extracts of different parts of Lantana camara. Asian Pac J Trop Biomed 2(12):960-965.

Mega IM, Swastini DA. 2010. Phytochemical screening and free antiradical activity of methanol extract of agarwood leaves (Gyrinops versteegii). J Kimia 4 (2): 187-192. [Indonesian]

Moalin M., van Strijdonck GPF, Beckers M, Hagemen GJ, Borm PJ, Bast A, Haenen GRMM. 2011. A planar conformation and the hydroxyl groups in the $\mathrm{B}$ and $\mathrm{C}$ rings play a pivotal role in the antioxidant capacity of quercetin and quercetin derivatives. Molecules 16:96369650 .

Nimse SB, Pal D. 2015. Free radicals, natural antioxidants, and their reaction mechanisms. RSC Adv. 5: 27986-28006.

Nuringtyas TR, Isomarina R, Septia Y, Hidayati L, Wijayanti N, Moeljopawiro S. 2018. The antioxidant and cytotoxic activities of the chloroform extract of agarwood (Gyrinops versteegii (Gilg.) Domke) leaves on $\mathrm{HeLa}$ cell lines. Proceedings of the $5^{\text {th }}$ International Conference on Biological Science, Volume 2002: 020067-1-0200679, Yogyakarta, 15-16 September 2017.

Pisoschi AM and Negulescu GP. 2011. Methods for total antioxidant activity determination: a review. Biochem \& Anal Biochem 1:106.

Prihantini AI, Tachibana S, Itoh K. 2014. Evaluation of antioxidant and $\alpha$ glucosidase inhibitory activities of some subtropical plants. Pak J Biol Sci 17 (10): 1106-1114

Prihantini AI, Tachibana S, Itoh K. 2015. Antioxidant active compounds from Elaeocarpus sylvestris and their relationship between structure and activity. Procedia Environ Sci 28:758-768.

Prihantini AI and Tachibana S. 2017. Antioxidant compounds produced by Pseudocercospora sp. ESL 02, an endophytic fungus isolated from Elaeocarpus sylvestris. Asian Pac J Trop Biomed 7(2):110-115.

Ramamoorthy PK, Bono A. 2007. Antioxidant activity, total phenolic and flavonoid content of Morinda citrifolia fruit extract from various extraction processes. J Eng Sci Tech 2 (1): 70-80.

Santoso E, Turjaman M, Irianto RSB, Agustini L, Efiyanti L, Faulina SA. 2014. $3^{\text {rd }}$ Topic of Agarwood. In: Kusumedi P, Hidayat B (eds). Forest Sciences and technology: $5^{\text {th }}$ Series. Badan Penelitian dan Pengembangan Kehutanan, Kementrian Kehutanan, Jakarta. [Indonesian]

Salamah E, Purwaningsih S, Permatasari E. 2011. Antioxidant activity and bioactive compounds of water cress (Nasturtium officinale L. R. Br). Jurnal Pengolahan Hasil Perikanan Indonesia XIV (2): 85-91. [Indonesian] 
Seal, Tapan. 2012. Antioxidant activity of some wild edible plants of Meghalaya State of India: a comparison using two solvent extraction systems. Int J Nutr Metab 4(3):51-56.

Siti HN, Kamisah Y, Kamsiah J. 2015. The role of oxidative stress, antioxidants and vascular inflammation in cardiovascular disease (a review). Vascul Pharmacol 71: 40-56.

Stankovic MS, Niciforovic N, Topuzovic M, Solujic S. 2014. Tota phenolic content, flavonoid concentrations and antioxidant activity, of the whole plant and plant parts extracts from Teucrium montanum 1 Var. montanum, f. Supinum (1.) Reichenb. Biotechnol Biotechnol Equip 25 (1): 2222-2227.
Tirzitis G and Bartosz G. 2010. Determination of antiradical and antioxidant activity: basic principles and new insights. Acta Biochim Pol 57(1):139-142.

Wojtunik-Kulesza KA, Oniszczuk A, Oniszczuk T, Waksmundzka-Hajnos M. 2016. The influence of common free radicals and antioxidants on development of Alzheimer's Disease. Biomed Pharmacother 78: 3949.

Young IS, Woodsida JV 2001. Antioxidant in health and disease. J. Clin Pathol 54: 176-186.

Zima TS, Fialova L, Mestek O, Janebova M, Crkovska J, Malbohan I, Stıpek S, Mikulıkova L, Popov P. 2001. Oxidative stress metabolism of ethanol and alcohol-related diseases. J Biomed Sci 8: 59-70. 